\title{
Community Interest Obligations in International Energy Law
}

\author{
Danae Azaria
}

\section{Introduction}

International energy law is the amalgam of rules of international law that regulate various energy-related activities, such as the exploration and exploitation of energy resources, trade, investment, transportation, distribution, and supply, as well as the effects of these activities, such as on the environment and on human rights. ${ }^{1}$ In light of the diversity of activities that the rules govern and the interests of states that the rules reflect, this field of international law is diverse in terms of the nature of obligations it encompasses. Some obligations are bilateral: They are either grounded in bilateral norms, such as bilateral treaties, or are found in multilateral norms, such as treaties or general customary international law, but translate into bundles of bilateralizable relationships between states. ${ }^{2}$ Other obligations protect community interests either of all states (erga omnes) or of groups of states (erga omnes partes). Determining the nature of an obligation in terms of the manner in which it is owed is a matter of interpretation. ${ }^{3}$ International courts have placed emphasis on a treaty's object and purpose in order to identify the nature of treaty obligations, ${ }^{4}$ and scholars have suggested that inter se modifications are prohibited in cases of treaties that establish community

${ }^{1}$ Catherine Redgwell, International Regulation of Energy Activities, in EnERgy LAW IN Europe 13, 16 (Martha Roggenkamp et al. eds., 2016).

2 This latter form of bilateral obligations can also be termed "bilateralizable obligations" to contrast it to the term "bilateral obligations," which are bilateral obligations based on bilateral norms. The term "bilateralizable obligations" will not be used in this analysis so as to ensure consistency in the terminology used in this volume. For use of the term "bilaterizable" in this context, see Danae Azaria, Treaties on Transit of Energy via Pipelines and Countermeasures 103-04 (2015); on bilateral obligations found in multilateral treaties, see Bruno Simma, Bilateralism and Community Interest in the Law of State Responsibility, in International Law at a Time of Perplexity 821, 822-23 (Yoram Dinstein ed., 1989).

${ }^{3}$ Int'l Law Comm'n, Rep. on the Work of Its Fifty-Third Sess., Draft Articles on Responsibility of States for Internationally Wrongful Acts, with Commentaries, U.N. Doc. A/56/10 (2001), reprinted in [2001] 2(2) Y.B. Int'l L. Comm'n 30, 118, U.N. Doc. A/CN.4/SER.A/2001/Add.1(Part 2) [hereinafter ILC Commentary to ASR]. In relation to treaty obligations, the customary rules on treaty interpretation set forth in the Vienna Convention on the Law of Treaties arts. 31-32, May 23, 1969, 1155 U.N.T.S. 331 [hereinafter VCLT] will be used in the following analysis.

${ }^{4}$ S.S. Wimbledon (U.K. et al. v. Ger.), Judgment, 1923 P.C.I.J. (ser. A) No. 1 (Aug. 17); Questions Relating to the Obligation to Prosecute or Extradite (Belg. v. Sen.), Judgment, 2012 I.C.J. Rep. 422 (July 20). 
interest obligations. ${ }^{5}$ This method will be used in the following analysis for the purpose of identifying the nature of obligations in the field of international energy law.

Whether obligations of international energy law are of a community interest nature (erga omnes or erga omnes partes) entails consequences in the law of international responsibility, which is to some extent reflected in the Articles on the Responsibility of States for Internationally Wrongful Acts (ASR) that were drafted by the International Law Commission (ILC) and commended by the General Assembly to the governments. ${ }^{6}$ More specifically, the nature of primary obligations determines who has standing to invoke the responsibility, and which "remedial rights" and enforcement means are available. $^{7}$

Another way of perceiving the place of community interest obligations within international energy law is through the prism of suspending performance of obligations of international energy law in response to breaches of community interest obligations. Owing to the importance that states attach to the energy sector, in the United Nations era where forcible responses to wrongfulness are prohibited, countermeasures in the form of suspending compliance with obligations in the energy sector carry significant persuasiveness. Some treaties that regulate the energy sector permit states to take energy-related measures for the enforcement of community interest obligations, such as the prohibition of aggression or the protection of human rights.

Section II of this chapter determines whether obligations which regulate energy activities are of a community interest nature. Section III examines obligations which regulate the effects of energy activities and considers whether they are of a community interest nature. Section IV discusses enforcement of community interest obligations by use of the energy sector. Section V provides some conclusions about the place of obligations in this field in the pendulum between bilateralism and community interest, and the contribution of this field to community interests in modern international law.

\section{The Nature of Rules Regulating Energy Activities}

Reciprocity and the making of bilateral obligations are dominant in international energy law. Before (and beyond) the conclusion of multilateral treaties that either

${ }^{5}$ Customs Regime Between Germany and Austria, Advisory Opinion, 1931 P.C.I.J. (ser. A/B) No. 41, at 64 (Sept. 5) (individual opinion by Dionisio Anzilotti); Oscar Chinn (U.K. v. Belg.), Judgment, 1934 P.C.I.J. (ser. A/B) No. 63, at 7, 131 (Dec. 12) (separate opinion of Judge van Eysinga).

6 Text of the Draft Articles, [2001] 2(2) Y.B. InT'L L. Comm'n 26, U.N. Doc. A/CN.4/SER.A/2001/Add.1 (Part 2) [hereinafter ASR]; G.A. Res. 56/83, Responsibility of States for Internationally Wrongful Acts (Jan. 28, 2002).

7 Injured states may invoke the responsibility claiming cessation, guarantees of non-repetition, and reparation (ASR, supra note 6, art. 42). States other than an injured state may invoke responsibility claiming cessation and guarantees of non-repetition (id. art. 48(2)(a)). As a progressive development, the latter may claim reparation in the interest of the injured state or of the beneficiaries of the obligation breached (id. art. 48(2)(b)); ILC Commentary to ASR, supra note 3, at 127 12. Injured states are entitled to resort to countermeasures (ASR, supra note 6, art. 49). It is unclear whether states other than the injured state may do so (ILC Commentary to ASR, supra note 3, at 129 g 8, p. 137 g 3, p. 139 gg 6-7). Contra Linos-Alexandre Sicilianos, Countermeasures in Response to Grave Violations of Obligations Owed to the International Community, in The Law of International Responsibility 1137, 1146-48 (James Crawford et al. eds., 2010). 
specifically deal with energy trade or also apply to energy trade, energy trade has fallen within the scope of bilateral treaties on friendship, navigation, and commerce. The Oil Platforms case (ICJ) was couched in terms of energy commerce and the application of the bilateral treaty of friendship and commerce between the U.S. and Iran. ${ }^{8}$ On the other hand, while multilateralism has increased, especially in the post-Cold War era, the advent of multilateral treaties (as norms) has not necessarily brought about genuinely multilateral obligations, meaning community interest obligations. ${ }^{9}$ The General Agreement on Tariffs and Trade (GATT), annexed to the Agreement Establishing the World Trade Organization (WTO Agreement), ${ }^{10}$ and the Energy Charter Treaty (ECT) ${ }^{11}$ do not perforce include community interest obligations (erga omnes partes), but mainly establish bilateral obligations, which are based on bilateralizable relationships between treaty parties.

Nevertheless, international energy law includes community interest obligations. The cornerstone rule of permanent sovereignty over natural resources, obligations concerning uninterrupted energy carriage under bespoke pipeline treaties (meaning treaties concluded for a particular transboundary pipeline), and human rights obligations, which may be interpreted as requiring states not to deprive individuals within their jurisdiction of access to energy, are some of these obligations. These are discussed in detail below, and are contrasted to bilateral obligations in this field.

\section{A. Permanent sovereignty over natural resources}

States enjoy permanent sovereignty over natural resources (PSNR) in areas where they exercise sovereignty (i.e., in their territory, internal waters, and territorial sea) and sovereign rights (i.e., in their continental shelf and exclusive economic zone). They do not enjoy PSNR over territory acquired forcibly at the expense of another state (annexation): Such acquisition is prohibited in international law. ${ }^{12}$ Nor do they acquire sovereignty over occupied territories. Under the law of occupation, the Occupying Power only acquires control over territory, and bears specific rights and duties under customary international law, including in relation to immovable and movable public and private property, such as energy resources and products. ${ }^{13}$

${ }^{8}$ Oil Platforms (Iran v. U.S.), Judgment, 1996 I.C.J. Rep. 817, 38 (Dec. 12); Oil Platforms (Iran v. U.S.), Judgment, 2003 I.C.J. Rep. 161, gg 23-84 (Nov. 6).

${ }^{9}$ For the distinction between multilateral norms and obligations, see James Crawford, Chance, Order Change: The Course of International Law, 365 Collected Courses of the Hague Academy of Int'L L. 9, 186 (2013).

${ }_{10}$ Marrakesh Agreement Establishing the World Trade Organization, Apr. 15, 1994, 1867 U.N.T.S. 154; General Agreement on Tariffs and Trade, Apr. 15, 1994, Marrakesh Agreement Establishing the World Trade Organization, Annex IA, 1867 U.N.T.S. 187.

11 Energy Charter Treaty, Dec. 17, 1994, 2080 U.N.T.S. 95, as amended by the Final Act of the International Conference and Decision by the Energy Charter Conference in respect of the Amendment to the Trade-Related Provisions of the Energy Charter Treaty, Annex 1 (adopted Apr. 24, 1998, entered into force Jan. 21, 2010).

12 Legal Consequences of the Construction of a Wall in the Occupied Palestinian Territory, Advisory Opinion, 2004 I.C.J. Rep. 136, 87 (July 9) [hereinafter Wall Case].

${ }_{13}$ See Hague Convention (IV) Respecting the Laws and Customs of War on Land and Its Annex: Regulations Concerning the Laws and Customs of War on Land arts. 42-56, Oct. 18, 1907, 205 C.T.S. 277; Eyal Benvenisti, The International Law of Occupation 6 (2d ed. 2012); Yoram Dinstein, The International Law of Belligerent Occupation 31, 42-43 (2009). 
PSNR is a rule of customary international law. ${ }^{14}$ Although in the 1970s arguments were voiced that PSNR is a peremptory norm of international law (jus cogens), there is no evidence in state practice to support this proposition. ${ }^{15}$ Quite the contrary, PSNR is expressly subject to rules of international law in numerous multilateral treaties (of global and regional accession terms), for example Article 193 of the Law of the Sea Convention (UNCLOS), ${ }^{16}$ ECT Article 18(1), and Article 18 of the ECOWAS Energy Protocol. ${ }^{17}$ Expressing consent to be bound by treaties that include such provisions denotes the understanding of treaty parties that PSNR under customary international law is a rule of jus dispositivum. The following sections examine the content of PSNR in order to distill whether it reflects community interests.

\section{Free disposal of energy resources}

The basic tenet of the rule concerning PSNR is that the state exclusively chooses whether resources will be explored and exploited, and if so, who will explore and exploit them, and how. This decisionmaking power also implies that the state has exclusive access to confidential information about nonliving resources (their location, features, and the economic feasibility of their exploitation). ${ }^{18}$

In the decolonization era, claims regarding PSNR were motivated by efforts to reinforce the sovereignty of newly independent states and other developing states, and later by the intention to ensure benefits for nonself-governing peoples. ${ }^{19}$ It was conceived as a means for gaining control over natural resources against former colonial powers and foreign companies, and was instrumental in nationalization processes. ${ }^{20}$ The debates between states, which led to the formation of customary international law, reflected the need to balance the interests of the newly independent and developing countries with those of developed countries, who wanted to see their nationals (investors) protected abroad. These debates found a forum in the UN General Assembly, which adopted a series of Resolutions. ${ }^{21}$ In this context, the main theme

14 Armed Activities on the Territory of the Congo (Dem. Rep. Congo v. Uganda), Judgment, 2005 I.C.J. Rep. 168, 244 (Dec. 19); Texaco Overseas Petroleum Company v. Libyan Arab Republic (1979), 53 I.L.R. 279, at 389; Amoco Int'l Fin. Corp. v. Iran (1987), 15 Iran-U.S. Cl. Trib. Rep. 189.

${ }^{15}$ In support of the position that PSNR is a rule jus cogens, see Eduardo Jiménez de Aréchaga, International Law in the Past Third of a Century, 159 Collected Courses of the Hague Academy OF INT'L L. 1, 297 (1978); Literature rejecting the jus cogens character of the rule, see Ian Brownlie, Legal Status of Natural Resources in International Law: Some Aspects, 162 Collected Courses of the HaGUe Academy of Int'L L. 253, 310 (1979); Nico Schrijver, Sovereignty over Natural Resources 377 (1997).

16 U.N. Convention on the Law of the Sea, Dec. 10, 1982, 1833 U.N.T.S. 397 [hereinafter UNCLOS].

17 ECOWAS Energy Protocol, Jan. 31, 2003, 42 ECOWAS O.J. 71. A/P4/1/03.

18 Dispute Concerning Delimitation of the Maritime Boundary Between Ghana and Côte d'Ivoire in the Atlantic Ocean (Ghana v. Côte d'Ivoire), Case No. 23, Order 2016/4 of Apr. 25, 2016, g9 61-62, 94, https://www.itlos.org/fileadmin/itlos/documents/cases/case_no.23_merits/C23_Ord_2016-4_25.04.16. pdf.

19 SCHRIJver, supra note 15 , at 20.

20 Texaco Overseas Petroleum Company v. Libyan Arab Republic (1979), supra note 14, at 389; Amoco Int'l Fin. Corp. v. Iran, supra note 14.

${ }^{21}$ G.A. Res. 1803 (XVII), Permanent Sovereignty over Natural Resources (Dec. 14, 1962); G.A. Res. 3201 (S-VI), Declaration on the Establishment of a New International Economic Order (May 1, 1974); G.A. Res. 3281 (XXIX), Charter of Economic Rights and Duties of States (Dec. 12, 1974). 
has been the scope of the exercise of PSNR by the host state, in the sense of the latter's regulatory power over the rights of foreign investors (especially under oil concession contracts), and the conditions under which such power can be exercised pursuant to customary international law. ${ }^{22}$

PSNR corresponds to an obligation of all states not to exploit another state's resources without the latter's consent. This obligation can be classified as an obligation erga omnes for two reasons. First, exclusive control over the resources in a state's territory (or in marine spaces within national jurisdiction) is claimed as against the world, not in a bilateral/reciprocal manner between the sovereign state and other states. Second, since PSNR is an aspect of self-determination, ${ }^{23}$ which corresponds to an obligation erga omnes, ${ }^{24}$ it may be argued that the obligation of states not to exploit the energy resources of other states without the latters' consent is an obligation of the same character. By analogy, the treaty reflections of this rule (e.g., ECT Article 18; ECOWAS Energy Protocol Article 18) establish obligations erga omnes partes.

\section{Exercise in the interest of the people}

The connection of PSNR with self-determination entails the obligation of states to exploit natural resources in the interest of the people and national development. ${ }^{25}$ A treaty reflection of this aspect of PSNR can be found, for instance, in Article 21(1) of the African Charter on Human and Peoples' Rights, ${ }^{26}$ which stipulates that "[a]ll peoples shall freely dispose of their wealth and natural resources. This right shall be exercised in the exclusive interest of the people." The manner in which this is to be achieved is not prescribed in the African Charter. However, it is reasonable to argue that it requires states not to exploit their energy resources exclusively for the benefit of another state or private entities, completely disregarding the needs of their domestic population or depriving it of means of subsistence. ${ }^{27}$

Article 1(2) both of the International Covenant on Civil and Political Rights (ICCPR $)^{28}$ and the International Covenant on Economic, Social and Cultural Rights (ICESCR ${ }^{29}$

22 The obligation to treat investors of another state in a particular manner does not translate into an erga omnes obligation; such customary rule is based on reciprocity-nationality being the predominant reasoning of such obligation-and standing to bring a claim for a breach is based on diplomatic protection. Barcelona Traction, Light and Power Company, Limited, (Belg. v. Spain), Judgment, 1970 I.C.J. Rep. 3, 32, g9 69-70 (Feb. 5).

${ }^{23}$ Commission on Human Rights, Rep. of the Tenth Sess., U.N. Doc. E/2573, at 35-38 (1954).

24 East Timor (Port. v. Austl.), Judgment, 1995 I.C.J. Rep. 102, 29 (June 30); Wall case, supra note 12, gg $88,155-56$.

25 See G.A. Res. 1803 (XVII), supra note 21, 1 , which makes this connection and which was adopted by eighty-seven votes to one and three abstentions in the GA Second Committee, the Resolution itself being adopted by eighty-seven in favor, two against, and twelve abstentions.

26 African Charter on Human and Peoples' Rights art. 5, June 27, 1981, 1520 U.N.T.S. 217 [hereinafter African Charter].

27 SERAC v. Nigeria, No. 155/96, African Court on Human and Peoples' Rights [Afr. Ct. H.P.R.], g9 55-58 (Oct. 27, 2001), http://www.achpr.org/files/sessions/30th/comunications/155.96/achpr30_155_96_ eng.pdf.

${ }_{28}$ International Covenant on Civil and Political Rights, Dec. 16, 1966, 999 U.N.T.S. 171 [hereinafter ICCPR].

${ }^{29}$ International Covenant on Economic, Social and Cultural Rights, Dec. 16, 1966, 993 U.N.T.S. 3 [hereinafter ICESCR]. 
does not refer to the obligation of treaty parties to exercise PSNR in the interest of their people. However, the implication of the right of people to freely dispose of their natural resources therein is arguably that states are obliged to exercise PSNR for the benefit of their people. These provisions at a minimum require that a people is not to be deprived "of its own means of subsistence," which may be interpreted to include some access to energy sources to ensure subsistence.

The obligation to dispose of energy resources in the interest of the people does not mean that states cannot export energy products to other states. One major benefit to hydrocarbon-endowed countries comes from trading such products. The obligation to exploit natural resources for the benefit of the people is better understood as imposing a requirement to design energy policies and negotiate agreements with third states in good faith, with a view to achieving the best possible benefit for the domestic population from energy exports.

\section{Exercise in the interest of third states and other people}

PSNR does not require states to exploit their energy resources for the benefit of other states or people in other states. However, other international law rules, such as those concerning world trade as well as human rights, may limit PSNR in this respect.

WTO-covered agreements do not oblige states to explore and exploit their energy resources with a view to supplying them to international markets. WTO Members may choose to exploit their exhaustible resources, such as hydrocarbons, at whatever rate they choose, for their own progress and economic development. ${ }^{30}$ GATT Article XI prohibits export restrictions or equivalent measures on energy products, if and once these have been exploited and are placed on the market. Additionally, WTO members may take measures that are, prima facie, inconsistent with this obligation, as long as these measures meet the requirements of the GATT exceptions, including the one concerning the conservation of exhaustible resources (Article XX(g)). Such conservation measures may involve the control of the extraction rate of an exhaustible natural resource, such as an oil or gas deposit, but do not have to take the form of a moratorium on exploitation. However, they cannot be taken with a view to controlling and regulating a natural resource market. ${ }^{31}$

ICECSR Article 2 provides that states are obliged "to take steps, individually and through international ... co-operation, especially economic and technical, ... with a view to achieving progressively the full realization of the rights recognized in the present Covenant by all appropriate means. ..."32 This provision is not restricted to measures that a state takes within its domestic legal order, but provides for international economic cooperation. It may thus be argued that it requires states to enter into good faith negotiations with other states in need of access to resources for the realization of economic, social, and cultural rights within their jurisdiction. It does not, however, require states to exploit and to make available to other states energy resources for the

${ }^{30}$ Panel Report, China-Measures Related to the Exportation of Rare Earths, 7.263, WTO Doc. WT/ DS431/R (Mar. 26, 2014) [hereinafter China-Rare Earths].

31 Id. 7.268 .

32 Ben Saul, David Kinley \& Jaqueline Mowbray, The International Covenant on Economic, Social and Cultural Rights: Commentary, Cases, and Materials 133-72 (2014) (art. 2(1)). 
realization of such rights in the jurisdiction of these other states; nor does it prohibit export restrictions (and equivalent measures).

\section{B. A human right to energy}

Access to energy (oil, gas or electricity) is indispensable for heating, cooking, use of medical equipment at home and in hospitals, and ensuring access to water, including for sanitation. There is no treaty specifically establishing a human right to energy, or referring to energy in connection with the rights established in the treaty. The only exception is Article 14(2) of the Convention on the Elimination of Discrimination against Women, which obliges parties to take all appropriate measures to eliminate discrimination against women in rural areas and in particular to ensure their right to enjoy adequate living conditions, particularly in relation to electricity. This provision focuses on a particular group of beneficiaries ("women in rural areas"), owing to their vulnerability, and is limited in terms of purpose ("elimination of discrimination").

It may be argued that when states arbitrarily deprive individuals of access to energy they may violate their obligations under treaty (and custom, where available) ${ }^{33}$ not to employ degrading treatment, ${ }^{34}$ to protect the right to life, ${ }^{35}$ and to respect the right to health ${ }^{36}$ and the right to housing. ${ }^{37}$ In relation to degrading treatment, in Francine van Volsem, a complaint was brought before the European Commission on Human Rights against Belgium for a violation of Article 3 of the Convention for the Protection of Human Rights and Fundamental Freedoms (ECHR). The claimant lived in an apartment where no alternative sources of heating were available. She argued that Belgium had violated ECHR Article 3 because Belgium permitted the interruption of the electricity supply to her apartment. In 1991, the European Commission on Human Rights rejected the admissibility of this complaint, because "in the case at issue, the cutting off or the threat of cutting off electricity did not reach the level of humiliation or debasement needed for there to be inhuman or degrading treatment." 38

This decision does not rule out the possibility that interfering with access to electricity may meet the threshold of treatment that would be inhuman or degrading. However, the decision did not provide detailed reasoning as to the level of humiliation that was needed in such situations: For instance, the fact that the economic conditions

${ }^{33}$ For the prohibition of inhuman treatment, right to life, and right to health being rules of customary international law, see Human Rights Committee, General Comment 24, 8, U.N. Doc. CCPR/C/21/Rev.1/ Add.6 (1994); Brigit Toebes, The Right to Health as a Human Right in International Law 83 (1999).

${ }^{34}$ ICCPR, supra note 28, art. 7; Convention for the Protection of Human Rights and Fundamental Freedoms art. 3, Nov. 4, 1950, 213 U.N.T.S. 221 [hereinafter ECHR]; American Convention on Human Rights art. 5, Nov. 22, 1969, 1144 U.N.T.S. 143 [hereinafter ACHR]; African Charter, supra note 26, art. 5.

${ }_{35}$ ICCPR, supra note 28, art. 6; ECHR, supra note 34, art. 2; ACHR, supra note 34, art. 4; African Charter, supra note 26, art. 4.

${ }^{36}$ ICESCR, supra note 29, art. 12; ECHR, supra note 34, art. 8 (private life) has been interpreted as inclusive of the right to health: Nada v. Switzerland, 2012-V Eur. Ct. H.R. 115, 151; Glor v. Switzerland, 2009 Eur. Ct. H.R., g 54.

37 European Social Charter art. 31(1), Oct. 18, 1961, 529 U.N.T.S. 89.

38 van Volsem v. Belgium, 2 Revue Universelle des Droits De L'Homme 384 (1990) (emphasis added). 
of the applicant were poor, her mental and physical state, the duration of the lack of electricity, the weather conditions during which it took place, and the fact that the facilities in her residence allowed for no alternative energy sources. ${ }^{39}$

Subsequent case law of the European Court of Human Rights (ECtHR) has taken into account conditions that were present in the case of the applicant in Francine van Volsem. It has clarified that the "absence of . . . a purpose [to humiliate] cannot conclusively rule out a finding of a violation of Article 3,"40 and that a breach of Article 3 may occur "in circumstances [where the individual is] wholly dependent on State support, [and is] faced with official indifference when in a situation of serious deprivation or incompatible with human dignity." ${ }^{\prime 1}$ Interruptions of energy access to vulnerable individuals may amount to violations of the right to be free from degrading treatment.

Additionally, interruptions of energy access may violate the right to health (ECHR Article 8; African Charter Article 16). The African Commission has interpreted the right to health under the African Charter as requiring states to provide basic services including safe drinking water and electricity. ${ }^{42}$ Moreover, the case law of the European Committee of Social Rights has recognized that the right to adequate housing under the European Social Charter includes a dwelling with all basic amenities, such as electricity."

As a separate matter, some domestic law and case law offers instances of state practice supporting the view that deprivation of electricity may violate the right to life or health. For instance, some domestic courts have found that deprivation of electricity may violate constitutional provisions either concerning human dignity ${ }^{44}$ or the right to life, or the right to health and physical integrity. ${ }^{45}$ This limited state practice is not sufficient evidence of uniform state practice necessary for the formation of a rule of customary international law, nor is there evidence of opinio juris. However, such a rule may emerge in the future, assuming that widespread state practice emerges followed by opinio juris.

\section{Energy trade in the WTO}

Under the 1947 GATT, disputes concerning energy trade were not prominent. ${ }^{46}$ The WTO Agreement does not include a framework agreement on energy trade. In the

39 Antonio Cassese, Can the Notion of Inhuman and Degrading Treatment Be Applied to Socio-Economic Conditions?, 2 Eur. J. INT'L L. 141 (1991).

40 Valašinas v. Lithuania, 2001-VIII Eur. Ct. H.R. 385, g 101.

${ }^{41}$ M.S.S. v. Belgium, 2011 Eur. Ct. H.R., g 253.

42 Free Legal Assistance Group v. Zaire, Communication 25/89, African Commission on Human Rights and Peoples' Rights [Afr. Comm'n H.P.R.], 47 (October 1995); for right to health in general under ECHR, see supra note 36.

${ }^{43}$ Centre on Housing Rights and Evictions v. Italy, Complaint No. 58/2009, European Committee on Social Rights, 54 (June 25, 2010).

441975 Syntagma [Syn.] [Constitution] 2(1); Symboulion Epikrateias [S.E.] [Supreme Administrative Court] 1972/2012, \$25 (Greece).

${ }^{45}$ Corte Constitucional [C.C.] [Constitutional Court], diciembre 11, 2015, Sentencia T-761/15, $\$ 4.1-$ 4.4 (Colom.).

46 However, there is no evidence that the terms "goods" or "products" in the 1947 GATT did not encompass energy goods and products. The only 1947 GATT case that dealt with energy activities was Panel Report, United States-Taxes on Petroleum and Certain Imported Substances, L/6175 GATT BISD (adopted June 17, 1987). 
first two decades of the life of the WTO Agreement debates about and disputes concerning energy trade were not prominent in the WTO context. Nevertheless, the scope of application of the WTO Agreement encompasses a number of aspects of the energy sector (e.g., trade of energy products under GATT, trade services under the GATS, or subsidies under the SCM Agreement). ${ }^{47}$ Since the beginning of the twenty-first century, WTO members have turned their attention to the application of the WTO Agreement to energy trade, either in the context of the negotiations for the amendment of the WTO Agreement, ${ }^{48}$ or by initiating proceedings under the Dispute Settlement Understanding (DSU) ${ }^{49}$ A number of reasons may have prompted this shift. First, numerous oil- and gas-exporting and transit states have acceded to the WTO. As of 20 June 2016, eight of the twelve members of the Organization of Petroleum Exporting Countries (OPEC) $)^{50}$ and seven of the eleven state parties to the Gas Exporting Countries Forum (GECF) are WTO members. ${ }^{51}$ Second, the need to mitigate climate change and energy security concerns have prompted states (and regional economic integration organizations) to promote the extensive use of renewable energy. This has given rise to disputes about the compatibility of the implementation of these policies with trade liberalization obligations. ${ }^{52}$

Community interests - some of which may be reflected in international obligations of WTO members outside the WTO-are taken into account by WTO provisions. An example is GATT Article XX on general exceptions, which permits the taking of measures for the conservation of exhaustible natural resources. ${ }^{53}$ This issue is further discussed in Section III.A below.

The rest of this section discusses the nature of WTO obligations, which has been the focus of lengthy scholarly debates following two landmark WTO cases: EC-Bananas ${ }^{54}$

${ }^{47}$ General Agreement on Trade in Services, Apr. 15, 1994, Marrakesh Agreement Establishing the World Trade Organization, Annex IB, 1869 U.N.T.S. 185; Agreement on Subsidies and Countervailing Measures, Apr. 15, 1994, Marrakesh Agreement Establishing the World Trade Organization, Annex IA, 1869 U.N.T.S. 14 [hereinafter SCM Agreement].

48 Indicatively: WTO Negotiating Group on Trade Facilitation, Communication from Armenia, the EC, FYROM, the Kyrgyz Republic, Mongolia, Paraguay, Moldova, Rwanda, and Switzerland, WTO Doc. TN/ TF/W/133, p. 1, 1 (July 10, 2006).

${ }^{49}$ Indicatively: Appellate Body Report, US-Standards for Reformulated and Conventional Gasoline, WTO Doc. WT/DS2/AB/R (adopted May 20, 1996); Appellate Body Report, Canada-Certain Measures Affecting the Renewable Energy Generation Sector, WTO Doc. WT/DS412/AB/R (May 24, 2013); Request for Consultations, EU and certain Member States-Certain Measures Affecting the Renewable Energy Generation Sector, WTO Doc. WT/DS452/1 (Nov. 5, 2012).

50 Angola, Ecuador, Kuwait, Nigeria, Qatar, Saudi Arabia, United Arab Emirates, and Venezuela. Agreement Concerning the Creation of the Organization of Petroleum Exporting Countries, Nov. 14, 1960, 443 U.N.T.S. 247.

51 Bolivia, Egypt, Nigeria, Qatar, Russia, Trinidad and Tobago, and Venezuela. The GECF members account for almost $70 \%$ of the world's proven natural gas reserves: Agreement on the Functioning of the Gas Exporting Countries Forum, Dec. 23, 2008, 2684 U.N.T.S. 27.

52 See supra note 49.

53 Measures falling within such exceptions may be taken in order to comply with environmental obligations or obligations for the conservation of exhaustible natural resources. In relation to conservation of energy resources, see infra, Section III.A.

${ }^{54}$ Panel Report, EC-Regime for the Importation, Sale and Distribution of Bananas, WTO Doc. WT/ DS27/R/USA (Sept. 25, 1997) as modified by Appellate Body Report [hereinafter EC-Bananas]. 
and US-Tax Treatment for "Foreign Sales Corporations." ${ }^{\text {"55 }}$ EC-Bananas dealt with standing to bring a claim under the WTO DSU for a breach of the GATT. In its reasoning, the Panel did not uphold that the GATT obligations are erga omnes partes. ${ }^{56}$ Rather, its reasoning was based on the factual interconnectedness of international markets and the risk of economic impact, including in the form of supplies and prices, faced by any other WTO member in cases where GATT violations occur. In support of its findings, the Panel cited the Judgment of the Permanent Court of International Justice (PCIJ) in S.S. Wimbledon, ${ }^{57}$ as well as the provisionally adopted ILC Draft Articles on State Responsibility (1996), particularly Article 40(e) and (f), which encompass bilateral, interdependent, and community interest obligations. By not distinguishing among these bases of standing, the Panel opened the debate about whether GATT obligations are erga omnes partes.

In US-Tax Treatment for "FSC," the Arbitrator did not deal with standing, but with the quantitative amount of the countermeasure agreed between the parties to the dispute. He found that the prohibition of the subsidy under the SCM Agreement was an erga omnes obligation. ${ }^{58}$ However, his reasoning does not support the suggestion that WTO obligations (or obligations of the SCM Agreement specifically) are community interest obligations. He based his finding on the measures' effects, rather than on the obligation's nature and the treaty's object and purpose. ${ }^{59}$

Scholarship has been divided on the matter. While Carmody claimed that WTO obligations are collective (erga omnes partes), ${ }^{6}$ Pauwelyn argued that WTO Agreement obligations are bilateral, ${ }^{61}$ and Gazzini argued that while WTO obligations are bilateral, wider standing has been extended to certain WTO obligations. ${ }^{62}$

In light of the above, it is better to classify WTO obligations as bilateral, while all WTO members have standing to invoke through the DSU responsibility for breach of WTO obligations, owing to the manner in which the DSU has been interpreted. ${ }^{63}$ Such community interest standing fittingly applies to the international and regional energy markets, given the interdependence of oil, gas, and electricity prices and the interdependence of importers and exporters.

\section{The Energy Charter Treaty}

The ECT is the first sector-specific treaty governing numerous aspects of the energy sector: Trade (Article 29), transit (Article 7), foreign investment (Part III), protection

55 Decision of the Arbitrator, US-Tax Treatment for "Foreign Sales Corporations"-Recourse to Arbitration by the US Under Article 22.6 of the DSU and Article 4.11 of the SCM Agreement, WTO Doc. WT/DS108/ARB (circulated Aug. 30, 2002).

56 Panel Report, EC-Bananas, supra note 54, 7.50. $\quad{ }^{57}$ Supra note 4.

58 Decision of the Arbitrator, US-Tax Treatment for "Foreign Sales Corporations," supra note 55, g 6.10.

${ }^{59}$ Id. 6.8 .

${ }^{60}$ Chios Carmody, WTO Obligations as Collective, 17 Eur. J. InT'L L. 419 (2006).

${ }^{61}$ Joost Pauwelyn, A Typology of Multilateral Treaty Obligations: Are WTO Obligations Bilateral or Collective in Nature?, 14 EUR. J. INT'L L. 907 (2003).

62 Tarcisio Gazzini, The Legal Nature of WTO Obligations and the Consequences of Their Violation, 17 EUR. J. INT'L L 723, 741 (2006).

${ }^{63}$ James Crawford, Multilateral Rights and Obligations in International Law, 319 ColleCted Courses of the Hague ACAdemy of Int'L L. 325, 451 (2006); Azaria, supra note 2, at 126-30. 
of the environment (Article 19), competition (Article 6), and permanent sovereignty over energy resources (Article 18). It also incorporates numerous dispute settlement provisions: Between investors and ECT Contracting Parties, as well as between ECT Contracting Parties. The discussion as to whether and if so to what extent the ECT contains obligations that reflect community interests is of wider importance, because treaties that transpose the ECT verbatim, such as the Energy Protocol to the Revised Treaty of the ECOWAS, have been concluded. The analysis here is relevant mutatis mutandis to the latter.

The nature of ECT obligations has yet to be addressed in the publicly available ECT case law. The following analysis will show that there is no evidence that all treaty obligations were intended to protect an overarching community interest beyond the individual interests of each Contracting Party. Rather, each obligation has to be examined separately.

ECT Article 2 is entitled "Purpose" and reads: "This Treaty establishes a legal framework in order to promote long-term cooperation in the energy field, based on complementarities and mutual benefits, in accordance with the objectives and principles of the Charter." The Preamble emphasizes the importance of trade liberalization, and the nondiscrimination principle enunciated in GATT, the national and most favored nation (MFN) treatment of foreign investors, and the urgent need to protect the environment, as well as the necessity for the most efficient transport of energy. The title "Energy Charter Treaty" corroborates the "constitutional" purpose of the treaty, and Article 2 ("Purpose") denotes the drafters' endeavor to establish a basal instrument governing their long-term relationships in the energy field.

The ECT legal framework is "based on complementarities and mutual benefits." According to the Oxford English Dictionary, the word "complementarity" means "a complementary relationship or situation"; "complementary" means "mutually complementing or completing each other's deficiencies." The wording "complementarities and mutual benefits" implies reciprocity on the basis of bilateral obligations. The immediate context of these terms is "in accordance with the objectives and principles of the Charter." By virtue of this language, the European Energy Charter (Charter), which is a nonbinding declaration that preceded and foresaw the conclusion of the ECT, informs the treaty's purpose. The Charter does not indicate anything more than the economic rationale of the cooperation envisaged among signatories. Article 2 reflects the economic bargaining that negotiating states envisaged. The drafters recognized the complementarities among them and envisaged benefits for all, rather than for one party or a particular group over another. ${ }^{64}$

The treaty's negotiating history leads to similar conclusions. It was negotiated partly in parallel with and concluded after (but was not legally associated with) the practice and agreements settling the independence and secession from the Union of Soviet Socialist Republics. It was also negotiated in parallel with the WTO Uruguay Round between 
1991 and $1994,{ }^{65}$ and was to prepare the ground for long-term energy cooperation in the post-Cold War era.

None of the dispute settlement mechanisms to which Contracting Parties may resort to implement the responsibility of another Contracting Party for a breach of an ECT obligation contains detailed rules on standing. Standing to resort to dispute settlement depends on the nature of each obligation the breach of which would be invoked. The following sections argue that each ECT obligation is of a different nature. Some obligations are bilateral; others protect the community interests of Contracting Parties.

\section{Investment protection}

The ECT obligations concerning investment protection (Part III and Article 26) apply solely to investors that bear the nationality of other Contracting Parties. They do not extend to all foreign investors in Contracting Parties or to investors that are nationals of a host Contracting Party. It could be argued that the protection of investors of another Contracting Party is widened because the definition of "investment" (Article $1(6)(b))$ is such as to require the host Contracting Party to treat a locally incorporated company in conformity with the ECT investment obligations, and that this feature turns these obligations into erga omnes partes. ${ }^{66}$ However, the by implication purpose of the provision, which widens the scope of "investment" and by implication of the definition of "investor," is not to treat foreign and domestic investors in the same manner, with a view to protecting any corporate entity per se. Rather, the purpose is to protect the interests of as many investors of other Contracting Parties as possible. It could also be argued that the manner in which the most-favored nation (MFN) treatment works in practice means that investors of numerous Contracting Parties may be affected by a breach of the ECT, and that this feature turns investment obligations into erga omnes partes obligations. ${ }^{67}$ However, the obligation concerning the MFN treatment is characterized by an exchange of treatment. As such, it reflects the individual interest of each treaty party to see its own nationals being protected abroad.

Seen through these lenses, the ECT investment protection obligations rest on the foreign nationality of another Contracting Party and on a predominantly individual interest of each Contracting Party to see their nationals protected abroad, rather than on a community interest that involves the protection of all corporate entities within their jurisdiction. They are bilateral obligations. ${ }^{68}$ Only individually injured Contracting Parties may resort to general inter-Contracting-Party dispute settlement in cases of breach of such obligations (Article 27). ${ }^{69}$

${ }^{65}$ The WTO Agreement, supra note 10, was concluded on Apr. 15, 1994, while the ECT, supra note 11, was done on Dec. 17, 1994.

${ }^{66}$ See argument mutatis mutandis in relation to bilateral investment treaties: STEPHAN W. SCHILL, The Multilateralization of International Investment LaW 202 (2009).

${ }^{67} \mathrm{Id}$. at $218-19$.

${ }^{68}$ Giorgio Gaja, The Concept of the Injured State, in The Law of International Responsibility, supra note 7 , at $943,944$.

${ }_{69}$ ECT, supra note 11, art. 27(2) expressly excludes from the inter-ECT Contracting Parties ad hoc arbitral tribunal's jurisdiction the last sentence of art. 10(1). Disputes concerning Part III, including the rest of the provisions of art. 10, are within the jurisdiction of the arbitral tribunal. 


\section{Trade and transit}

The obligations on trade (Article 29) and transit (Article 7) are better classified as bilateral, since trade and transit are based on reciprocal exchanges between parties. ${ }^{70}$ The subsequent practice of Contracting Parties in the application of Article 7 and Article 29 is inconclusive as to the nature of the obligations in Articles 7 and 29. First, where either violations of transit and exports obligations have occurred or the lawfulness of the measures taken could at least have been challenged, Contracting Parties, which would be states "other than the injured state" if obligations under Articles 7 and 29 were classified as erga omnes partes, did not make claims of "relatively formal form" for the cessation of the wrongful acts. ${ }^{71}$ However, neither did injured states (specially affected, if the obligations are erga omnes partes, or individually injured, if the obligations are bilateral) make claims mentioning the nature of treaty obligations. Second, subsequent practice of ECT Contracting Parties in the form of concluding subsequent (implementation) agreements between some ECT Contracting Parties provides evidence that priority is given to the ECT in case of conflict between the ECT and these agreements. This feature may support the conclusion that the ECT is an integral nature treaty, and contains erga omnes partes obligations. ${ }^{72}$ For instance, all parties to the Nabucco Pipeline Agreement ${ }^{73}$ and the Trans-Adriatic Pipeline (TAP) Treaty $^{74}$ are ECT Contracting Parties. The Nabucco Pipeline Agreement explicitly does not derogate from the ECT and the founding EU treaties (Article 3(1)), and the TAP Treaty is in furtherance of the ECT according to its Preamble. However, while these may indicate that the treaty parties do not intend to conflict with and depart from their ECT obligations, it is unclear that they do so specifically owing to the community interest nature of the ECT trade and transit obligations.

In the absence of evidence to the contrary, and given that trade and transit are characterized by reciprocal exchanges, it is better to classify obligations in Articles 7 and 29 as bilateral. Only specially affected Contracting Parties (individually injured) can resort to conciliation concerning transit disputes under Article 7 (Article 7(7)) or to general inter-Contracting Party dispute settlement (Article 27) for breaches of Article 7. Since trade obligations (Articles 5 and 29) are bilateral, standing to resort to Annex D of the ECT should be available only to individually injured Contracting Parties. However, it is arguable that given the intention in the ECT negotiations to parallelize Annex D to the WTO DSU, Annex D may be interpreted as affording more generous standing to all ECT Contracting Parties, despite the fact that obligations in Articles 5 and 29, disputes over which shall be settled through Annex D, are bilateral.

${ }^{70}$ Even if all other ECT obligations were erga omnes partes, art. 29 may a contrario establish bilateral obligations given that it has been consistently treated as separate from other provisions of the ECT: ECT art. 24 (exceptions) does not apply to art. 29 (ECT art. 24(1)), and disputes concerning art. 29 can only be settled through Annex D (unless pursuant to art. 28 the parties to the dispute agree to submit their dispute to ad hoc inter-ECT Contracting Party arbitration under art. 27).

${ }_{71}$ See state practice in the context of trade and transit disputes, AzARIA, supra note 2, at 89-94.

72 Supra note 5.

73 Agreement Among the Republic of Austria, the Republic of Bulgaria, the Republic of Hungary, Romania, and the Republic of Turkey Regarding the Nabucco Project, July 13, 2009, 2742 U.N.T.S. 353.

${ }^{74}$ Agreement Among the Republic of Albania, the Hellenic Republic, and the Italian Republic Relating to the Trans Adriatic Pipeline Project, Feb. 13, 2013 (entered into force Feb. 19, 2014), https://treaties. un.org/doc/Publication/UNTS/No\%20Volume/52254/Part/I-52254-08000002803fb77b.pdf. 


\section{Environmental concerns}

ECT Article 19 deals with the protection of the environment from energy activities. ${ }^{75}$ Paragraph 1 requires Contracting Parties to "strive to minimize . . . harmful Environmental Impacts occurring either within or outside its Area from all operations within the Energy Cycle in its Area. . ." Contrary to the UNCLOS, in which the term "Area" means "the seabed and ocean floor and subsoil thereof, beyond the limits of national jurisdiction" (Article 1(1)), the term "Area" in the ECT means spaces within national jurisdiction (Article 1(10)): "[W]ith respect to a state that is a Contracting Party ["Area” means]: (a) the territory under its sovereignty, it being understood that territory includes land, internal waters and the territorial sea; and (b) subject to and in accordance with the international law of the sea: the sea, sea-bed and its subsoil with regard to which that Contracting Party exercises sovereign rights and jurisdiction."

Article 19 deals with environmental harm occurring outside the jurisdiction of the Contracting Party where the harmful energy activity takes place, as well as with environmental harm occurring in the jurisdiction of the Contracting Party in whose jurisdiction the harmful energy activity takes place. It is arguable that the obligation to prevent transboundary harm in a space under the jurisdiction of another state (but not a space beyond national jurisdiction, such as the high seas or the Area under UNCLOS) is a bilateral obligation: The underpinning rationale of that obligation is the harm to another state, rather than a stand-alone interest regarding the protection of the environment. ${ }^{76}$ However, the obligation in Article 19(1) is different. In the absence of any requirement connecting jurisdiction and harm, the obligation in Article 19(1) is not based on a bilateral relationship between Contracting Parties, whose environment would be affected by a harmful energy activity. Rather, it protects a community interest-the environment per se-and is best classified as an obligation erga omnes partes. Therefore, any Contracting Party may resort to dispute resolution under Article 19(2) for a breach of obligations in Article 19, even when the environmental harm occurs within the Area of the same Contracting Party in whose Area the harmful energy activity takes place.

\section{E. Bespoke treaties for energy projects}

Since World War II, treaties have been concluded for the construction and operation of transboundary pipelines. This trend has intensified since the post-Cold War period. The literature reveals a trend involving the conclusion of "plurilateral" bespoke pipeline treaties. ${ }^{77}$

\footnotetext{
75 For an overview of the provision, see Clare Shine, Environmental Protection Under the Energy Charter Treaty, in The Energy Charter Treaty 520 (Thomas Walde ed., 1996).

76 Trail Smelter (U.S. v. Can.), 3 R.I.A.A. 1905, 1965 (1941).

77 The term "plurilateral" is merely descriptive of the treaties' form (being multilateral but with a limited number of treaty parties). It is not intended to be a classification with legal consequences in the law of treaties. Azaria, supra note 2, at 116-24.
} 
Some of these treaties - such as the Nabucco Pipeline Agreement, the TAP Treaty, and the West Africa Gas Pipeline (WAGP) Treaty ${ }^{78}$ - owing to their object and purpose ${ }^{79}$ establish erga omnes partes obligations concerning uninterrupted energy carriage. The primary interest that these obligations protect is the collective energy security of treaty parties and the protection of a particular regime. ${ }^{80}$

Rules of international energy law govern a variety of activities in the energy sector. They are found in treaties and custom, but no jus cogens norms have appeared as yet. Although bilateral obligations remain relevant, especially in relation to the economic activities in the energy sector (such as energy trade and investment), there are obligations which reflect community interests either of all states (erga omnes obligations) or of groups of states (erga omnes partes obligations) under treaties, such as permanent sovereignty over natural resources, obligations concerning the protection of the rights of individuals connected to access to energy, and obligations concerning uninterrupted energy carriage via pipelines in some bespoke pipeline treaties. ${ }^{81}$

Having examined economic activities in the energy sector, the following section deals with the community interest obligations that regulate the effects of energy activities.

\section{The Nature of Rules Regulating the Effects of Energy Activities}

Although states are free to design their own energy policies, the effects of energy activities can be multifaceted and significant. Treaties and custom require states to address certain effects of such activities. The following sections examine whether community interest obligations require states to conserve exhaustible energy resources, such

78 Treaty on the West African Gas Pipeline Project Between the Republic of Benin, the Republic of Ghana, the Federal Republic of Nigeria, and the Togolese Republic, Jan. 31, 2003, http://www.wagpa.org/ Treaty_on_WAGP_Project.pdf.

${ }^{79}$ The ICJ has placed emphasis on the object and purpose of the Convention Against Torture in order to determine the nature of obligations therein as erga omnes partes: Questions Relating to the Obligation to Prosecute or Extradite, supra note 4, 968.

${ }^{80}$ AzARIA, supra note 2, at 116-21, 123-24.

81 Others include freedoms of the high seas (of navigation and of laying pipelines and cables), as well as the obligation to make contributions for the exploitation of the continental shelf beyond 200 nautical miles, which is a reflection of the erga omnes partes regime of the Area under UNCLOS. Although no international court or tribunal has pronounced on the community interest nature of the obligation not to interfere with freedoms of the high seas, some state practice supports this understanding of the rule. In 1973, Australia argued that France's nuclear tests in the Pacific Ocean violated freedom of navigation on the high seas, and that Australia had standing owing to the erga omnes nature of this obligation: Memorial on Jurisdiction and Admissibility submitted by Australia, 23 November 1973, Nuclear Tests (Austl. v. Fr.), 1974 I.C.J. Rep. 253, 462 (Dec. 20). In 2014, the Netherlands claimed that freedom of navigation (in the EEZ) is an obligation erga omnes partes under UNCLOS and erga omnes under custom, and that it thus had standing to invoke Russia's responsibility for interference with such freedom: Arctic Sunrise Arbitration (Neth. v. Russ.), Award on the Merits, 182 (Per. Ct. Arb. 2015), http://www.pcacases. $\mathrm{com} / \mathrm{web} / \mathrm{send}$ Attach/1438. The Tribunal did not find it necessary to address this point, since it had established standing on the basis that the Netherlands was the flag state. 
as hydrocarbons, to prevent environmental harm from energy activities and to protect human rights, when they undertake or authorize energy activities within their jurisdiction.

\section{A. Conservation of energy resources}

Since states are free to dispose of their natural resources, they may manage and conserve natural resources pursuant to their national developmental and environmental policies. ${ }^{82}$ International law does not oblige states to conserve hydrocarbon resources which fall exclusively within one state's jurisdiction, or to exploit them on the basis of particular rates. ${ }^{83}$ If it existed, such an obligation would be better classified as a community interest obligation, because it would protect an interest that cannot be analyzed as a bundle of bilateral relationships between states. It would protect energy resources per se, either because this type of obligation also encompasses obligations that protect an integral self-standing interest, or because conservation protects a community interest to preserve resources in the name of future generations, as an aspect of sustainable development. ${ }^{84}$

Some treaties (and arguably custom) ${ }^{85}$ stipulate sustainable use of some living resources, such as fisheries, and transboundary nonliving resources, such as freshwater which may constitute an energy source (by producing hydroelectricity). However, it is doubtful that such a rule applies to hydrocarbons within the jurisdiction of one state. ${ }^{86}$ It is also doubtful that a general rule on sustainable development exists under customary international law, ${ }^{87}$ one which would require states to exploit their exhaustible hydrocarbon resources for the benefit of future generations on the basis of prescribed depletion rates.

82 SChrijver, supra note 15 , at 391.

${ }^{83}$ In relation to law of the sea, see David Ong, Towards an International Law for the Conservation of Offshore Hydrocarbon Resources Within the Continental Shelf?, in THE LAw of THE SEA 93, 96-107 (David Freestone et al. eds., 2006); Danae Azaria, The Scope and Content of Sovereign Rights in Relation to Non-Living Resources in the Continental Shelf and the Exclusive Economic Zone, 3 J. TERRITORIAL \& MAR. STUD. 5, 11-15 (2016).

${ }^{84}$ On aspects of sustainable development, see Philippe SANDS Et Al., Principles of International ENVIRONMENTAL LAW 206-17 (3d ed. 2012).

85 Patricia Birnie et al., International Law and the Environment 199-200 (2009).

${ }^{86} \mathrm{Id}$.

87 Vaughan Lowe, Sustainable Development and Unsustainable Arguments, in International LAw and Sustainable Development 19-37 (Alan Boyle \& David Freestone eds., 1999). Boyle and Freestone persuasively argue that although international law does not require states to develop sustainably, it does require them to make development decisions that are "the outcome of a process which promotes sustainable development." See Alan Boyle \& David Freestone, Introduction, in InTERnational LAW AND Sustainable Development, supra, at 1, 17. While in Gabćíkovo-Nagymaros Project (Hung. v. Slovk.), Judgment, 1997 I.C.J. Rep. 7, 140 (Sept. 25), the ICJ referred to the "concept" (rather than principle or rule) of sustainable development, the Arbitral Tribunal in Indus Waters Kishenganga Arbitration (Pak. v. India), Partial Award, gg 449-50 (Perm. Ct. Arb. 2013) referred to the "principle of sustainable development," as did a WTO Panel in China-Rare Earths, supra note 30, 7.262. For criticism of the latter cases' reasoning, see Azaria, supra note 83, at 13-15. 


\section{B. Protection of the environment from the effects of energy activities}

General customary internationallaw obliges states to prevent significant transboundary harm, including that caused by energy activities. ${ }^{88}$ It does not oblige states to prevent such harm within their own jurisdiction (except vis-à-vis the marine environment). ${ }^{89}$ It is arguable that the obligation to prevent transboundary harm to a space under the jurisdiction of another state (but not a space beyond national jurisdiction) is a bilateral obligation: The underpinning rationale of that obligation is the harm to another state, rather than a stand-alone interest in the protection of the environment. ${ }^{90}$

On the other hand, obligations to prevent harm without such jurisdiction criterion are better classified as erga omnes partes obligations (or erga omnes, if they exist under custom), because the primary interest protected by these obligations is one beyond the individual interests of states. For instance, UNCLOS parties are required to protect and preserve the marine environment without any restrictions on the basis of a transboundary effect or on the basis of a jurisdiction criterion (Article 192). The exploitation of offshore oil and gas deposits in the continental shelf or the placement and operation of wind farms in the exclusive economic zone is subject to the coastal state's duty to protect the marine environment in general, including within its own national jurisdiction. ${ }^{91}$

\section{Protecting individuals from the effects of energy activities}

Human rights obligations par excellence protect community interests. These obligations delineate the manner in which states may undertake energy activities within their jurisdiction or authorize and permit private entities to conduct such activities within their jurisdiction. Decisions of regional human rights courts and commissions have pronounced that the right to health (ECHR Article 8), ${ }^{92}$ the right to property (ACHR Article 21), ${ }^{93}$ and the right to a healthy environment (African

\footnotetext{
88 BIRNiE ET AL., supra note 85 , at 137,167 . The obligation to prevent transboundary harm translates into procedural obligations, whose customary nature has been identified in the following case law: Pulp Mills on the River Uruguay (Arg. v. Uru.), Judgment, 2010 I.C.J. Rep. 14, gg 204-05 (Apr. 20) [hereinafter Pulp Mills]; Corfu Channel (U.K. v. Alb.), Judgment, 1949 I.C.J. Rep. 4, 22 (Apr. 9). UNCLOS, supra note 16, also contains relevant procedural obligations: arts. 204-06.

${ }^{89}$ International case law has only found violations of the obligation not to cause (and subsequently to prevent) transboundary harm (or harm in the context of a shared resource), not of harm to the environment within one state's jurisdiction: Trail Smelter, supra note 76, at 1965; Corfu Channel, supra note 88, at 22; Legality of the Threat or Use of Nuclear Weapons, Advisory Opinion, 1996 I.C.J. Rep. 242, 9 29 (July 8); Pulp Mills, supra note 88, 9 101. Cf. Iron Rhine Railway (Belg. v. Neth.), 27 R.I.A.A. 35, g 59 (Hague Arb. Trib. 2005). The relevant passage in the latter award could be interpreted as recognizing an obligation to prevent environmental harm generally only by taking the tribunal's reasoning out of the dispute's context, which involved harm caused by the activities of one state (Belgium) taking place in the territory of another state (the Netherlands). Contra SANDS ET AL., supra note 84, at 201.

90 Trail Smelter, supra note 76, at 1965.

91 These are obligations of due diligence and, similarly to the obligation to prevent transboundary harm, they entail by necessary implication a number of procedural obligations for coastal states: the obligation to notify, to undertake an environmental impact assessment, and to monitor the energy activity in question. See supra note 88.

92 See case law, supra note 36.

93 Saramaka People v. Suriname, Preliminary Objections, Merits, Reparations, and Costs, Judgment, Inter-Am. Ct. H.R. (ser. C) No. 172, gg 77-185 (Nov. 28, 2007).
} 
Charter Articles 16 and 24) ${ }^{94}$ may be affected by industrial (and energy-related) activities within one state's jurisdiction. Their decisions have reached similar (but not identical) conclusions. ${ }^{95}$ More specifically, states are obliged to act diligently in adopting and enforcing legislation vis-à-vis major industrial projects within their jurisdiction that may affect human rights: They are obliged to require the conduct of environmental impact assessments prior to the authorization of energy projects, to continue to monitor the projects, and to provide information to the communities exposed to the hazardous activities and give them meaningful opportunities to be heard and to participate in the decisions. ${ }^{96}$

Under human rights treaties, judicial or quasi-judicial fora have been established. Affected individuals and any treaty party may resort to these fora in order to implement the responsibility of a treaty party for a breach of a human rights obligation. In this manner, human rights obligations, as well as those that may invoke their breach, individuals and other states may indirectly shape national energy policies.

\section{Enforcing Community Interest Obligations by Energy-Related Measures}

Trade rules are deferent to the need for trade to be used as a means of enforcing (extraneous) community interest obligations. For instance, GATT Article XXI(b)(iii) and ECT Article 24(3)(a)(ii) provide "security exceptions" that permit parties to take measures inconsistent with GATT and ECT respectively "[f]or the protection of [their] essential security interests taken in time of . . . other emergency in international relations." For instance, in 2014 the U.S. and the EU resorted to measures prima facie inconsistent with GATT and the GATS: Export restrictions on energy-related equipment and the provision of services for deep-water oil exploration and production and Arctic oil exploration and production against Russia following the latter's illegal annexation of Crimea in breach of the prohibition of use of force. ${ }^{97}$

Although such provisions have not been crafted to address exclusively situations where parties respond to prior violations of (extraneous) community interest obligations (under treaties or custom), their scope allows such measures. ${ }^{98}$

94 SERAC v. Nigeria, supra note 27, 92.

95 For a thorough analysis from the point of view of the effect on the environment, see Alan Boyle, Human Rights and the Environment: Where Next?, 23 Eur. J. INT'L L. 613 (2012).

96 SERAC v. Nigeria, supra note 27, 53; SERAP v. Nigeria, Judgment No. ECW/CCJ/JUD/18/12, ECOWAS Court, g 107-08 (Dec. 14, 2012), http://www.courtecowas.org/site2012/pdf_files/decisions/ judgements/2012/SERAP_V_FEDERAL_REPUBLIC_OF_NIGERIA.pdf; Saramaka People v. Suriname, supra note 93, g9 77-185.

${ }_{97}$ On prohibition of use of force constituting an obligation erga omnes, see Dissenting Opinion of Judge Schwebel, Military and Paramilitary Activities in and Against Nicaragua (Nicar. v. U.S.), Provisional Measures, 1984 I.C.J. Rep. 169, 198 (May 10). For the more narrow category of aggression, see Barcelona Traction, supra note 22 , g9 33-34.

98 For countermeasures in the form of interrupting energy supply and the conditions of lawfulness of countermeasures, see Azaria, supra note 2, at 229-47; Danae Azaria, State Responsibility and Community Interest in International Energy Law: A European Perspective, 5 CAMBRIDGE J. InT'L \& Comp. L. 169 (2016). 


\section{Conclusion}

International energy law is an amalgam of different obligations concerning energy activities - the exploration and exploitation of energy resources, their trade and transportation, and investment in the energy sector-as well as the effects of these activities on the environment and on human rights. It is thus not surprising that it accommodates bilateral obligations, such as those under the WTO/GATT or investment protection under the ECT, as well as obligations that protect community interests either of all states (erga omnes) or of groups of states (erga omnes partes), such as those concerning the protection of the environment and human rights. Permanent sovereignty over natural resources, as the cornerstone rule in this field, can be classified as corresponding to an erga omnes obligation. This rule entails that states are free to dispose of their natural resources without the interference of other states. However, states are required to dispose of their natural resources in the interest of their people. They are obliged not to completely deprive their people of access to such resources or deprive them of the benefit from the exploitation of such resources.

Additionally, existing human rights obligations, such as the right to life, the right to be free from inhuman treatment, and the right to health entail that the state is obliged to ensure some access to energy sources. However, free disposal of natural resources means that states are not obliged to exploit their resources in the interest of third states and other people outside their jurisdiction. Human rights obligations, such as Article 2 of the ICCPR that requires states parties to take steps through international cooperation with a view to achieving progressively the full realization of the rights recognized in the ICCPR by all appropriate means, may be interpreted as requiring states to enter into good faith negotiations concerning the access of other states to their energy resources. However, that provision does not require that states exploit their energy resources in order to provide access to third states and people. Moreover, trade liberalization under the WTO does not require states to exploit their energy resources with a view to making them available for export to other states. Yet when such resources have been exploited, they are governed by the WTO rules. Energy activities may have significant effects on the environment, the resources themselves (especially exhaustible resources, such as oil and gas), and on the human rights of individuals and of indigenous peoples. Obligations concerning the protection of the environment, the conservation of resources (where such rules exist), and the protection of human rights, all of which are community interest obligations, shape national energy policies because they restrict the manner in which a state may undertake or permit energyrelated activities within its jurisdiction.

Finally, states place particular importance on economic activities in the energy sector, because of their significant energy security concerns (security of supply and security of demand). States may and often do invoke the responsibility of other states for a breach of international obligations which reflect community interests, such as the prohibition of the use of force and human rights obligations, by resorting to energyrelated countermeasures that involve the suspension of international obligations concerning energy trade, since such measures may carry considerable persuasiveness. 